\title{
PROGRESSIVE WAY OF THINKING ABOUT CONTEMPORARY EDUCATION - PERSONAL DISCUSSIONS
}

\author{
Tomasz Prauzner \\ Jan Dlugosz University in Czestochowa, Poland
}

\begin{abstract}
The article presents personal reflections related to the adaptation of education in terms of current social challenges. Selected teaching postulates will be presented in relation to the current experiences and needs of the education system in the period of pandemic restrictions. The questions included are intended to make the reader reflect and public debate on the innovative changes that await contemporary didactics. In addition, the article will present the elements of own research related to the observation of cognitive activity using QEEG electroencephalographic studies. The analysis of cognitive activity is a key element in the assessment of didactic effectiveness. Due to the wide scope of scientific research, only selected sources of the author's publications will be indicated, in which the topic has been presented in detail.
\end{abstract}

Keywords: education, didactics, QEEG encephalographic research, effectiveness of education, cognitive processes.

\section{Introduction}

The evaluation of each of the scientific sub-disciplines is based on constant changes resulting from current research conducted in its area. An important element is also forecasting its development directions based on past experiences and observations of the present. An example is the current pandemic situation related to the sudden and unpredictable COVID-19 virus spreading all over the world. In terms of educational practice and the functioning of education not only in the country but also around the world, its further direction of reorientation can be predicted. In my work, I will quote a number of statements by the authors to date in numerous scientific publications and I will try to relate them to the current challenges in terms of, for example, the effectiveness of education.

\section{Discussion}

The present period is often referred to as the period of development of civilization based on lifelong learning, knowledge-based society, globalization or 
computerization. The role of education is therefore to prepare a young person for lifelong learning. Knowledge is not given to us once and for all, it is redesigned with the progress of science and technology, with cultural and social changes, and with the development of the personality of the individual. As Pawłowski (2004) recalls, the personal qualities necessary for active functioning in the information society are: openness to the world, its curiosity, innovation, courage to think and act, social activity, broad knowledge and the ability to apply it, the ability to complete education throughout life, responsibility for words and deeds. In terms of education or broadly understood pedagogy, it is extremely important to precisely define its educational and upbringing challenges. One of the forms of this practice is lifelong learning. However, it will not be focused only on learning to be or learning to act, but also learning to know (Zarzecki, 2008). In addition, it can be observed that the main beneficiary of it is also an increasing group of people aged $40^{+}$, which proves that today's realities of professional work force people to continuous training. Thus, there is a need to update previously acquired information, for example through the exchange of daily work tools - this is primarily information technology based tools. The aim of these recommendations is to contribute to the development of high-quality education by supporting and complementing the efforts of Member States to develop initial education and training systems that provide all young people with the means to develop key competences. It is mainly about the ability to communicate, solve problems, logical thinking, leadership, creativity, motivation, the ability to work in a team and the ability to learn (Huk, 2007). Communication skills should be understood not only in relation to interpersonal skills, but most of all the ability to use online tools enabling participation in continuous didactic activity. The problem of transition from stationary activity to distance learning forces a rapid change in communication technology through the use of new forms of communication (Prauzner, 2018). In the field of vocational education, the widespread automation and computerization of production processes causes an increase in the demand for highly qualified employees, but at the same time a fairly large reduction in the number of employees. The results of research in the field of university education to date clearly show that the decisive role of teaching methods in shaping competences, both hard and soft, is overlooked. The methodology of general education indicates that the actual course of the education process - its meaning, value, goals and effectiveness - depends on the appropriate selection and application of education methods. The didactic value of modern online learning tools is gaining immense importance, especially in the current pandemic situation. An extremely important question arises, which takes on practical significance and reflects the real dimension of the role played by the computer in the didactic process - not only at the basic level, but as an operative tool supporting solving complex didactic and scientific problems. If these problems have occurred so far 
to such a noticeable degree, then a question arises about the quality of education that excludes learning in a group and only using only the virtual form of acquiring practical and social skills. There is no doubt that the method of remote participation in classes is perfect for transmitting the theoretical content of the material, at work with the use of computer simulations, but the question arises about practical skills, the remote transmission of which will still be based on virtual participation in classes (Prauzner, 2016 ). Remote learning based on human-computer interaction is therefore a perfect example when the student works alone based only on the entrusted teaching materials and a computer. This situation can therefore be identified with the commonly practiced method of distance learning at the polytechnic level. Computer simulations used during classes can be used not only in a stationary laboratory, but also in distance learning with free online access to simulation software. Therefore, the quality of education (effectiveness) must be assessed on the basis of current teaching practice, nowadays more and more carried out online. The QEEG encephalographic research method, the assumption and preliminary results of which will be presented later in the paper, may be useful in assessing this effectiveness.

\section{Methodology}

In terms of the effectiveness of education with the use of IT tools, research is carried out at the Laboratory of Experimental Research Biofeedback of the Jan Długosz University in Częstochowa. The research uses the Mitsar EEG 202 measuring apparatus. The QEEG research will provide significant quantitative data enabling the graphical interpretation of the brain activity during the student's work with a computer (working with a simulation program). This is research focused on polytechnic education among students of engineering studies. EEG electroencephalography is a non-invasive method of measuring the activity of the human nervous system. Brain mapping (QEEG - quantitative - that is, "quantitative" EEG), ie the quantitative measurement of electrical impulses on the surface of the human scalp, allows for a more precise observation of any changes in brain activity, taking into account their location. Therefore, we are dealing here with an assessment of the student's involvement in creative work at a computer workstation without the active participation of the teacher. Recording brain activity by measuring extremely low amplitude tensions recorded on the surface of human skin also has its drawbacks. This method enables the registration of changes in small voltage potentials thanks to the installed sensors. With regard to the cognitive process, however, we are interested in more complex mental activities, i.e. processes resulting from the complex cooperation of various areas of the brain. Taking into account the resulting differences in the structure and functioning of the brain in every human being, it can be noticed that the observed 
cognitive activity can be registered in different parts of the brain (Sadowski, Chmurzyński, 1989). Therefore, the indicator of the occurrence of a given variable will be not so much the topology of a given wave (related to elementary activities), but its occurrence, course and time of formation (Fig. 1).

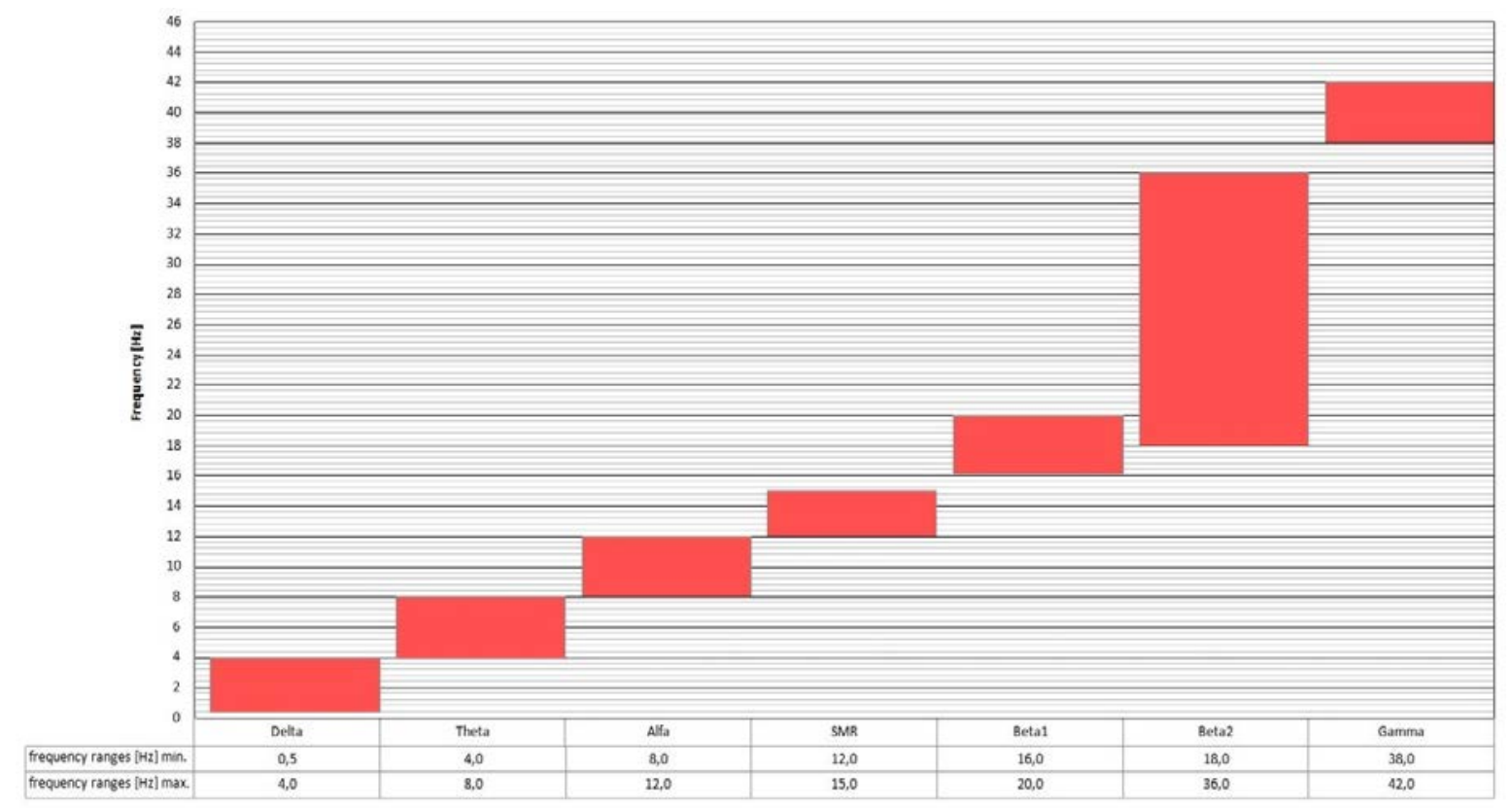

Figure 1 A Simplified Diagram of the Waves Occurring during the Research Source: Own Study Based on Thompson, 2003 et al.

The reflection of the work of neurons in the form of recorded impulses can be interpreted by a specific cognitive activity taking place in the brain and by the normal motor activity of the body. The element of observation is the course of selected wave frequencies that indicate the active work of the examined person:

Beta waves with a frequency from 12 to about $36 \mathrm{~Hz}$, with an amplitude below $30 \mu \mathrm{V}$. They illustrate the involvement of the cerebral cortex in cognitive activity. Generating a Beta wave is associated with wakefulness, vigilance, external orientation, and logical thinking, problem solving and attention. This wave will be seen while listening to the spoken text and while solving problems. The wide range of Beta can be broken down into smaller frequency ranges that correspond to a greater degree to the different ways in which the cerebral cortex functions (Thompson, 2012, p. 73). We observe these waves with inspiring energy, accompany action, characterize logical and analytical thinking, and intellectual commitment. A person is then conscious, focused on receiving external stimuli with the help of his five senses: sight, hearing, touch, taste and smell. 
Waves $(12-15 \mathrm{~Hz})$ of the so-called SMR, low Beta, known as the sensory rhythm, arises when receiving information from the five senses. Responsible for relaxing with external attention and problem-solving. Man is relaxed in this state, but ready to observe the world. Too low SMR levels accompany attention deficits.

Beta1 waves (16-20 Hz), the so-called Beta average, are associated with concentration on one issue, with external orientation (sometimes at frequencies above $20 \mathrm{~Hz}$ ). If a person is faced with the need to solve, for example, a mathematical problem, we will notice that first the amplitude of the activity will increase around $17 \mathrm{~Hz}$, and at the same time the amplitude of the Theta and low Alpha (8-10 Hz) will decrease (Thompson, 2012, p.74). This bandwidth correlates with the cognitive activity characteristic of active problem solving (intense mental effort). Mastering a new activity requires more Beta waves than doing it once it is mastered (Thompson, 2012). The higher the frequency, the greater the creative stimulation and abstract thinking, the attention is focused on the problem. We focus on performing tasks, then new ideas for solutions are born. Tasks are performed quickly and easily, the human being works with full attention. In this state, nerve impulses flow at lightning speed. A person can pursue ambitious goals, achieve intellectual heights. It accompanies the instant generation of new ideas. It enables the presentation, quick analysis and organization of information and any other activity where a fresh, fast-acting brain is needed, a key tool for our success.

Waves (18-36Hz), so called high Beta or Beta2 - a stressful wave of anxiety accompanies us during intense mental work. It is associated with increased emotional tension, because its emission accompanies the release of adrenaline responsible for the state of readiness of the body. For the above studies, it was judged rather undesirable.

Gamma waves. Sheer rhythm $(38-42 \mathrm{~Hz})$. It has been observed that this rhythm is important for the learning process. It can be related to the type of attention that is characteristic of the act of combining different aspects of an object to form a single concept. It is referred to by some clinicians as the consolidation rhythm and is believed to be associated with peak performance state (Thompson, 2012, p. 74). Sheer's rhythm is associated with the high attention and focus in solving problems. This frequency is difficult to measure in EEG studies because of human muscle artifacts (Thompson, 2012). They are also the only frequency group found in any part of the brain. This is why it is assumed that when the brain processes information in different parts simultaneously, it uses waves at a frequency of $40 \mathrm{~Hz}$. The Gamma wave is related to the processing of associative information (Krawczyk, 2018; Wietrzykowski, 2010). Its occurrence has also been noticed in extreme states of emotions and experiences. 


\section{Results of Research}

QEEG research was conducted on a randomly selected group of students in the 2019/20 academic year. Students were asked to perform an engineering project in the simulation software of their choice. The QEEG test consists in active registration and observation of the brain during work, therefore, due to the quantitative limitations of this method, the research was conducted only on a group of 50 people. An example of such a test while working with simulation software is shown in Figure 2.

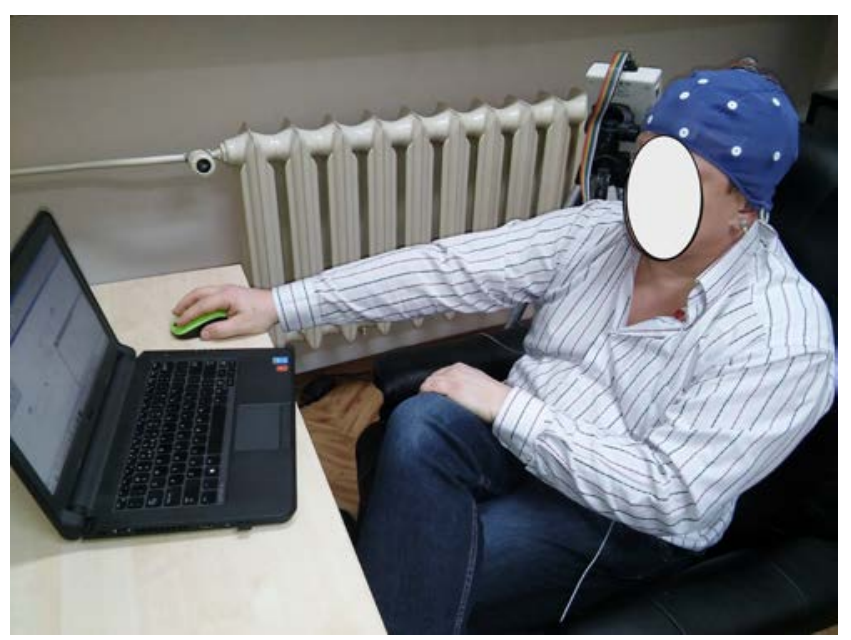

Figure 2 QEEG Testing while Working with the Simulation Program [own study]

After the end of the study, the first step was to remove the so-called artifacts, i.e. disturbances of various origins (Fig. 3).

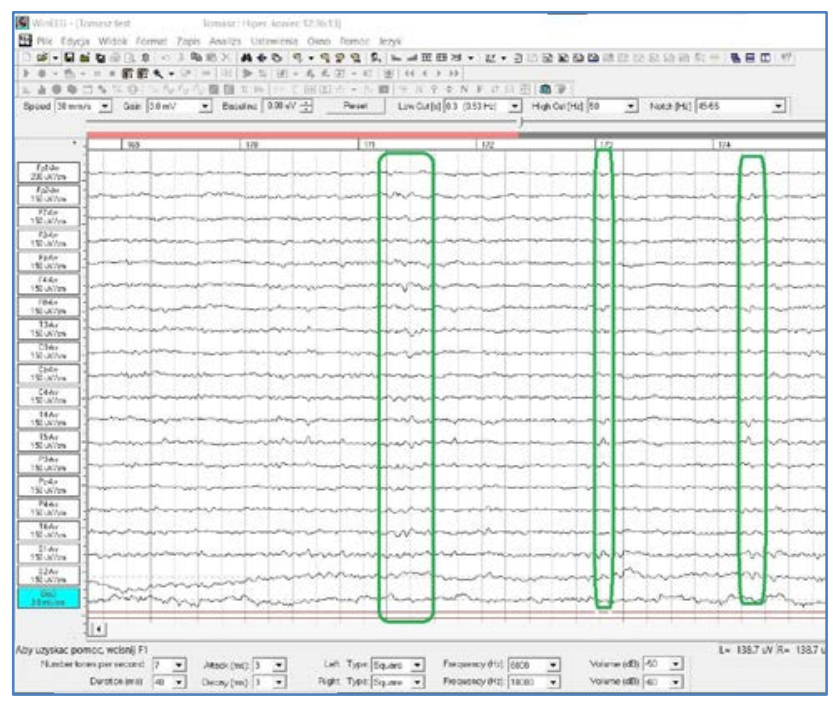

Figure 3 Initial Analysis of Recorded Data, Removal of Artifacts (green) [own elaboration] 
The recorded data were cleaned as precisely as possible from disturbances originating both from the power grid and the biological activity of the tested person generating disruptive indications from, for example, body movement, etc. executing a of 50 minutes. At that time, the researcher indexed the various stages of work in the program, while observing on the preview screen at what stage of work the student is. The final results are presented in numerous so-called maps of brain activity, which can be translated into Figure 4 .

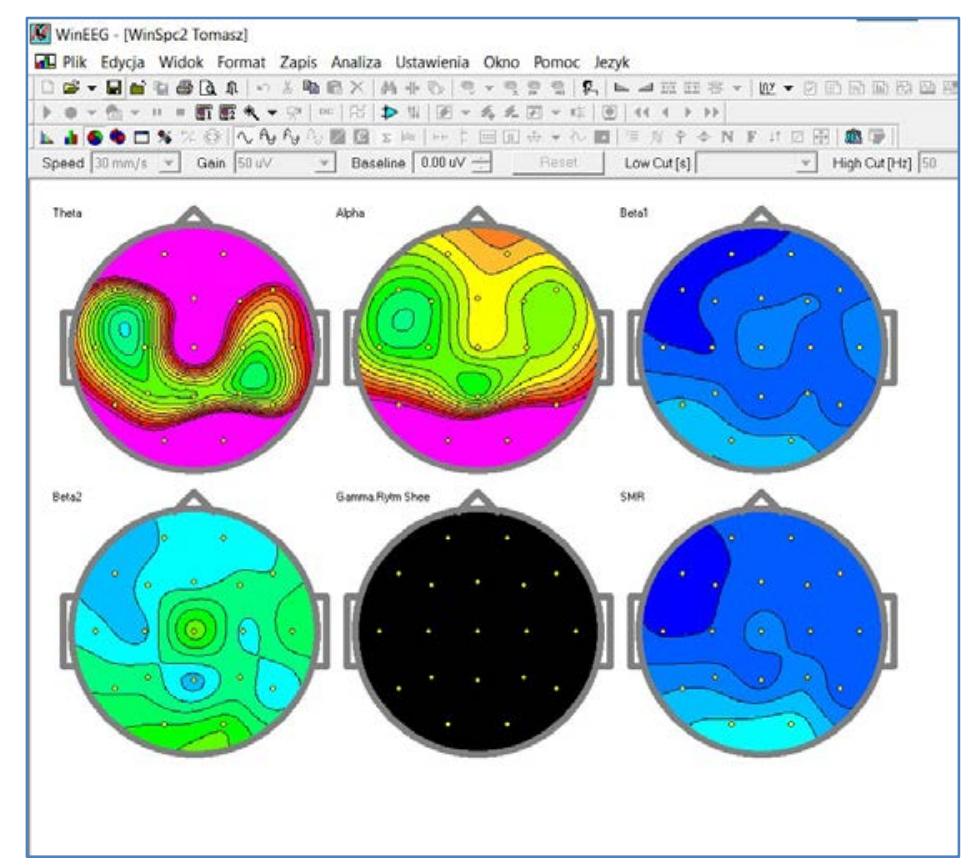

Figure 4 Sample Map of Brain Activity [own elaboration]

In the above case it can be seen that the activity of the brain is limited to the activity of the anterior and posterior parts of its structure, and in addition, the signal amplitude indicates the dominance of Theta and Alpha waves. So, to simplify, we deal with the lack of typical didactic activity, the brain in this state is only absorbed in abstract thinking and observation. These are the frequencies accompanying a person, e.g. during meditation, dreams, free observation of an image. Thoughts are inconsistent, logical connections disappear. Nevertheless, such a moment occurred in practically each of the respondents, especially at the beginning of work. It seems right, because in the first phase of work, a person is focused only on observing the workplace, observing the surroundings and then the image on the computer screen. Only at a later stage of the research, research activity was noticed in more than $67 \%$ of the respondents, observed on the basis of an increase in the amplitude of the time courses for the Beta 2 and SMR frequencies. At the same time, at the same time in over $50 \%$, significant activity of Beta1 waves was noticed, which may indicate a stressful situation related to 
the development of a mathematical model in the program. Unfortunately, this frequency very often occurs in people who have difficulties in correctly assessing their work, it occurs as a frequency that has a rather negative effect on the stabilization of the work of the mind, but it cannot be completely avoided. Moreover, in the mentioned case the Gamma frequency is practically imperceptible, unfortunately it is very often difficult to register due to its nature of the course, therefore its registration has been limited by software. Then, the data was ordered and additionally supplemented with the description resulting from the observations. Information sheets of people who participated in the research were analyzed, in which there questions were related to illnesses, injuries and medications taken. Obviously, the results of the research provided much more information, but it is impossible to present them in such a limited scope of publications, which is why I refer the reader to a number of other publications and scientific monographs issued by the author, indicated in the bibliography of the work.

\section{Concluding Remarks}

The studies conducted so far indicate that the presented EEG method, or rather QEEG, is perfect for assessing human activity under given working conditions (Prauzner, 2020). Numerous studies were conducted during the work of engineering students in the implementation of technical projects with the use of deterministic simulation programs (Ptak, Prauzner et al., 2012-20). In addition, selected factors accompanying the tests that could have a significant impact on the reliability of measurements with the Mitsar apparatus were determined (Prauzner, 2020). As research shows, thanks to the use of this method of observation, it can be noticed that cognitive activity depends not only on interpersonal features influencing the interest in the subject, but it shows that the composition of software use is extremely important. Elements such as legibility and understanding of concepts representing specific program functions, used iconographic signs, their arrangement and the logic of representation for the user are extremely important in the efficient use of the software. Of course, there are more of these elements, but the observation of brain activity at each stage of the work indicates that the user shows greater cognitive activity, and sometimes on the contrary (Prauzner, 2015-19). The presented research method is an alternative method to commonly conducted pedagogical research based on the evaluation of didactic activity, through a statistical analysis of the student's grades. However, from the point of view of psychology, we know perfectly well that each person has different interpersonal predispositions to specific activities and chooses the method of learning individually. This is due to the different structure of our brain, which for us is still an area that has only been discovered scientifically. The 
concept of individuality in science, a personality directing the pace of education, results from reasons that are often unintended by us. The current education system imposes a certain standardization of education, which, in my opinion, is not able to correctly assess the effects of a student's work. In history, you can find examples when now respected and capable people were critically assessed by the education system of that time. Therefore, I hope that the introduction of the EEG method in the field of pedagogical research may be a constructive element in the newly developing subdiscipline of pedagogy and neurodidactics.

\section{References}

Huk, T., (2007). Komputerowe wspomaganie procesu kształtowania umiejętności kluczowych uczniów szkół podstawowych. Uniwersytet Śląski, Wydział Pedagogiki i Psychologii, Katowice.

Krawczyk, J. (2018). Fale mózgowe - na jakich obrotach działa twój mózg? Retrieved from http://zdrowie.gazeta.pl.

Noga, H., Olszewska, D., Ptak, P., Prauzner, T., Migo, P., (2018). Badanie i symulacja oddziaływania zmiennego pola elektromagnetycznego na rozwój mikroorganizmów, Przeglad Elektrotechniczny, R 94, Nr 1/2018, 73-76.

Olszewska, D., Prauzner, T., Krupa, P., Ptak, P. (2018). Use of modern information technology in microbiological laboratory, Society. Integration. Education., Proceedings of the International Scientific Conference., Volume V, May 25th-26th, Rēzekne: Rèzeknes Augstskola, Latvia, 380-389.

Osiński, Z., (2010). Metody, formy i programy kształcenia. W poszukiwaniu efektywnych metod kształcenia uniwersyteckiego, E-mentor, nr 2 (34).

Pawłowski, K., (2004). Społeczeństwo wiedzy - szansa dla Polski, Wydawnictwo Znak, Kraków.

Prauzner,T., Ptak, P., (2018). Modelowanie i symulacja działania czujnika indukcyjnego pola magnetycznego, Przegląd Elektrotechniczny, R 94 Nr 1/2018, 89-92.

Prauzner, T. (2015). Analysis of the results of the pedagogical research and EEG in the aspect of effective modern teaching aids in the technical education. Society. Integration. Education., Proceedings of the International Scientific Conference., Volume IV, May 22th-23th 2015, Rēzekne: Rēzeknes Augstskola, Latvia, 480-489.

Prauzner, T. (2016). Interactive computer simulation as a response to contemporary problems of technical education, Society. Integration. Education., Proceedings of the International Scientific Conference, Volume II, May 27th - 28th, Rēzekne: Rēzeknes Augstskola, Latvia, 579-588.

Prauzner, T. (2017). The effectiveness of school education - featured implications considerations. Society. Integration. Education, Proceedings of the International Scientific Conference, Volume III, May 26th-27th 2017, Rēzekne: Rēzeknes Augstskola, Latvia, 558-564.

Prauzner, T. (2018). Cognitive mechanisms in the didactics of technical vocational subjects in the light of research on bioelectrical brain activity. Society. Integration. Education., Proceedings of the International Scientific Conference, Volume I, May 25th-26th, Rēzekne: Rēzeknes Augstskola, Latvia, 454-463. 
Prauzner, T., (2020). Innovativeness of didactic practice in the field of current pedagogical knowledge, Society. Integration. Education., Proceedings of the International Scientific Conference, Volume II, May 22th -23th, Rēzekne: Rēzeknes Augstskola, Latvia, 247-255.

Prauzner, T., Prauzner, M., Prauzner, K., Ptak, P. (2019). Cognitive activity in the respect of qeeg research - presentation of laboratory tests. Society. Integration. Education., Proceedings of the International Scientific Conference, Volume V, May 24th-25th, Rèzekne: Rēzeknes Augstskola, Latvia, 469-478.

Prauzner, T., Prauzner, K., Ptak, P., Noga, H., Migo, P., Depešová, J., (2020). Wpływ warunków otoczenia na dokładność badań elektroencefalograficznych QEEG (The influence of environmental conditions on the accuracy of QEEG electroencephalography). Przegląd Elektrotechniczny, R. 96, NR 4/2020, 86-89.

Ptak, P., (2015). Application of DasyLab in Teaching Electrical Engineering, Society, Integration, Education. Proceedings of the International Scientific Conference. Volume IV, May 22nd-23rd, 2015. Rēzekne: Rēzeknes Augstskola, Latvia, 490-499.

Ptak, P., (2016). Application of software packages in research and didactics, Society, Integration, Education. Proceedings of the International Scientific Conference, Volume II, May 27th-28th, 2016. Rēzekne: Rēzeknes Augstskola, Latvia, 589-597.

Ptak, P., (2017). Application of computer programmes in research projects and teaching, Society, Integration, Education. Proceedings of the International Scientific Conference, Volume III, May 26th-27th, 2017. Rēzekne: Rēzeknes Augstskola, Latvia, 565-574.

Ptak, P., (2018). Application of multisim and ltspice software packages to simulate the operation of electronic components as an alternative to measurements of real elements, Society, Integration, Education. Proceedings of the International Scientific Conference. Volume V, May 25th-26th, 2018. Rēzekne: Rèzeknes Augstskola, Latvia, 409-419.

Ptak, P., (2018). Application of the software package ltspice for designing and analysing the operation of electronic systems, Society, Integration, Education. Proceedings of the International Scientific Conference, Volume V, May 25th-26th, 2018. Rēzekne: Rēzeknes Augstskola, Latvia, 402-408.

Ptak, P., Borowik, L., (2012). Diagnostyka zabezpieczeń antykorozyjnych na potrzeby elektroenergetyki, Przegląd Elektrotechniczny, 2012 nr 09a, 142-145.

Ptak, P., Borowik, L., (2012). Dobór częstotliwości i rodzaju sygnału czujnika indukcyjnego na potrzeby pomiaru grubości wielowarstwowych powłok ochronnych, Przeglad Elektrotechniczny, $2012 \mathrm{nr}$ 12b, 245-247.

Ptak, P., Prauzner, T. (2019). The use of modern information technology in teaching electronics. Society. Integration. Education., Proceedings of the International Scientific Conference., Volume V, May 24th-25th, Rēzekne: Rèzeknes Augstskola, Latvia, 479-487.

Ptak, P., Prauzner, T., Noga, H., Migo, P., Depešova, J., (2020). Wykorzystanie pola magnetycznego do badania stanu powłok ochronnych, (The use of a magnetic field to study the condition of protective coatings). Przeglad Elektrotechniczny, R. 96 NR 2/2020, 114-116.

Sadowski, B., Chmurzyński, J.A. (1989). Biologiczne mechanizmy zachowania. Warszawa: PWN.

Thompson, M. (2012). In. M. Thompson (Eds.), Neurofeedback. Wprowadzenie do podstawowych koncepcji psychofizjologii stosowanej (The Neurofeedback Book. An Introduction to Basic Concepts in Applied Psychophysiology). Wrocław: Biomed Neurotechnologie. 
SOCIETY. INTEGRATION. EDUCATION

Proceedings of the International Scientific Conference. Volume I, May $28^{\text {th }}-29^{\text {th }}$, 2021. 502-512

Wietrzykowski, W. (2010). Biologiczna Sieć Pakietowa. Pobrane z: http://net3plus.awardspace.com.

Zarzecki, L., (2008). Wybrane problemy dydaktyki ogólnej, Wydawnictwo Kolegium Karkonoskie w Jeleniej Górze, Jelenia Góra. 